\title{
Tropospheric ozone retrieval by a combination of TROPOMI/S5P measurements with BASCOE assimilated data
}

\author{
Heue Klaus-Peter ${ }^{1,2}$, Loyola Diego ${ }^{1}$, Romahn Fabian ${ }^{1}$, Zimmer Walter ${ }^{1}$, Chabrillat Simon ${ }^{3}$, \\ Errera Quentin $^{3}$, Ziemke Jerry ${ }^{4}$, and Kramarova Natalya ${ }^{4}$ \\ ${ }^{1}$ Institut für Methodik der Fernerkundung am Deutschen Zentrum für Luft- und Raumfahrt (DLR), Oberpfaffenhofen, \\ Germany \\ ${ }^{2}$ Technische Universität München (TUM), Munich, Germany \\ ${ }^{3}$ Koninklijk Belgisch Instituut voor Ruimte-Aeronomie / Institut royal d'Aéronomie Spatiale de Belgique, Brussels, Belgium \\ ${ }^{4}$ NASA GSFC, Greenbelt, Maryland, USA
}

Correspondence: Klaus-Peter Heue: Klaus-Peter.Heue@ DLR.de

\begin{abstract}
We present a new tropospheric ozone data set based on TROMOMI/Sentinel-5 Precursor (S5P) total ozone measurements combined stratospheric ozone data from the Belgian Assimilation System for Chemical ObsErvations (BASCOE). BASCOE is constrained by assimilating ozone observations from the microwave limb sounder (MLS). The tropospheric ozone algorithm is similar to the well established OMI-MLS or OMPS-MERRA-2 retrieval. Compared to this we gain spatial resolution when applying the algorithm to TROPOMI data $\left(5.5 \times 3.5 \mathrm{~km}^{2}\right)$ and extend these data record into the future.

Compared to the OMPS-MERRA-2 data a mean positive bias of $\approx 3 \mathrm{DU}$ is found. A small negative bias of about $2 \mathrm{DU}$ is observed in the tropics relative to the operational TROPOMI tropospheric (S5P_O3_TCL) data based on the CCD algorithm. The new tropospheric ozone data (S5P-BASCOE) is compared to a set of globally distributed ozone sondes data integrated up to the tropopause level. For the comparison both the mean of the satellite observations around the sounding station and the closest column data are used. Depending on the latitude the S5P-BASCOE deviate from the sondes and between 0 and 5 DU, indicating a good agreement. However, some exceptional larger positive deviation up to $\pm 10 \mathrm{DU}$ are found. The monthly mean tropospheric column as well as time series for selected places showed the expected spatial and temporal pattern.
\end{abstract}

\section{Introduction}

Tropospheric ozone is an important pollutant because it is affects human health and crop growth. Especially respiratory and cardiovascular symptoms increase with short term exposure to enhanced ozone concentration (e.g. Fleming et al., 2018). In the global mean tropospheric ozone is responsible for about 10\% loss of the wheat production (e.g. Avery et al., 2011; Ainsworth et al., 2012). Depending on the region and the crop the loss may reach up to $25 \%$. In the troposphere ozone is produced by photochemical processes converting primary pollutants such as NOx and VOCs or directly by lightning. Stratospheric intrusion is another import source of tropospheric ozone. Due to its long lifetime of 20 to 30 days (e.g. Wu et al. , 2007) ozone can be transported over large distances. Moreover, tropospheric ozone acts as a greenhouse gas $(0.40 \pm 0.20 \mathrm{~W} \mathrm{~m}(? 2)$, IPCC, 2013(@) and is an important source of OH which controls the lifetime of many other atmospheric species. 
Currently several approaches are used to derive tropospheric ozone from satellite observations. In the tropics the Convective Cloud Differential method (Ziemke et al., 1998) can be used. The TROPOMI/S5P CCD tropospheric ozone (Heue et al. , 2016; Heue et al., 2020b) is generated operationally since the beginning of the mission in 2018. The vertical ozone column above deep convective clouds gives an estimate of the stratospheric ozone column. It is assumed that the stratospheric ozone column varies slowly in time and latitude but is longitudinal constant. The stratospheric background column is averaged for a certain reference region (Indian Ocean, Indonesia to the Pacific Ocean) and subtracted from the total column for cloud free observations.

Ziemke et al. (2006) presented a limb nadir matching approach based on the combination of nadir observations from OMI (Ozone Monitoring Instrument) and limb observations form the Microwave Limb Sounder (MLS), both on the NASA Aura satellite. The nadir viewing OMI observes the total column while MLS provides the ozone vertical distribution from $0.02 \mathrm{hPa}$ down to the tropopause. To retrieve the stratospheric column the MLS ozone profile is assimilated to Modern-Era Retrospective analysis for Research and Applications-2 (MERRA-2) and integrated above the tropopause. Both datasets are gridded to the same grid ( $1^{\circ}$ latitude $\mathrm{x} 1.25^{\circ}$ longitude) and only data with less than $30 \%$ cloud coverage are considered. The product was further improved and the OMI measurements were continued by OMPS (Ozone Mapping and Profiler Suite) Nadir observations (Section 3.2).

SCIAMACHY (Scanning Imaging Absorption Spectrometer for Atmospheric Chartography) on Envisat (2002-2012) was capable of observing both the total column in nadir and the stratospheric profile in limb geometry. Ebojie et al. (2014) published the latest update of the limb nadir matching data based on SCIAMACHY observation.

Miles et al. (2015) used an optimal estimation method (Rodgers, 2000) to retrieve the profile information from GOME, SCIAMACHY, OMI and GOME-2 nadir observations. The different sensitivity of the instruments to ozone absorption in the Hartley band and in the Huggins band and the temperature dependency of the ozone absorption cross section are the key parameters to retrieve the ozone profile. The data were analysed with ESA?s CCI project and are regularly updated for EU?s Copernicus Climate Change Service (C3S). The same physical background is used by Smithsonian Astrophysical Observatory (SAO) algorithm (Huang et al., 2017) to derive ozone profiles below $60 \mathrm{~km}$ with $2.5 \mathrm{~km}$ vertical resolution from OMI observations. Since December 2021 the TROPOMI/S5P operational ozone profiles (Veefkind et al., 2021) are available, which also contain a tropospheric ozone subcolumns up to $6 \mathrm{~km}$ and from $6-12 \mathrm{~km}$.

The above mentioned ozone profiles or tropospheric data are mostly based on the ozone absorption in the UV (260 to 360 $\mathrm{nm}$ ), except for MLS. The IASI (Infrared Atmospheric Sounding Interferometer) instruments on the MetOp (A, B and C) satellites make use of the infrared ozone absorptions between wavenumber 1025 and $1075 \mathrm{~cm}-1$. The FORLI (Fast Optimal Retrievals on Layers for IASI) algorithm (Boynard et al., 2018) is also based on an optimal estimation method and retrieves profiles of 39 layers up to $39 \mathrm{~km}$ altitude and one additional layer up to the top of atmosphere. The data are restricted to cloud coverage of less than $13 \%$. The comparison of the Tropospheric columns up to $300 \mathrm{hPa}$ showed a negative bias between 10 and $19 \%$ for tropical and mid-latitudes and a positive bias of $5 \%$ in the polar latitudes relative to ozone sondes. 

for the lower troposphere, below $3 \mathrm{~km}$. Both instruments are installed on the MetOp satellite series and collocated spectral observations are analysed simultaneously. The final data have the same spatial resolution as IASI.

The tropospheric ozone burden can be retrieved by assimilation of both the total ozone column and the stratospheric ozone profile using chemical transfer simulations. CAMS (Copernicus Atmosphere Monitoring Service) also uses $\mathrm{O}_{3}$ total columns from TROPOMI and other satellite instruments to constrain the total ozone and MLS for the stratospheric column. Inness et al. (2019) showed that the additional assimilation of TROPOMI ozone columns improves the data quality in the tropical to mid-latitude troposphere.

In this study we introduce a new tropospheric ozone dataset S5P-BASCOE, based on TROPOMI/S5P total ozone measurements and stratospheric ozone data provided by the Belgian Assimilation System for Chemical ObsErvations (BASCOE) constrained by MLS ozone profiles. It makes use of the high spatial resolution of the TROPOMI instrument $\left(5.5 \times 3.5 \mathrm{~km}^{2}\right)$. Sentinel 5P was launched in October 2017 and together with the future Sentinel-5 mission it will provide global measurements during the next decade. The BASCOE stratospheric ozone system provides a forecast, of stratospheric ozone profiles. In combination with the near-real-time (NRT) S5P total ozone columns the tropospheric ozone column may also be provided three hours after sensing.

In the first section the tropospheric ozone retrieval is presented including a brief introduction of the total ozone column algorithm as well as the BASCOE assimilation. In the following sections the tropospheric ozone column data sets (OMPS-MERRA, S5P_CCD) and ozone sondes will be explained briefly. The next section contains comparisons among these tropospheric ozone data. Finally, tropospheric results will be presented and briefly discussed.

\section{Troposperic Ozone Retrieval}

\subsection{S5P-BASCOE}

The S5P-BASCOE tropospheric ozone retrieval is based on a three step approach. In a first step the total ozone column is retrieved from the TROPOMI/S5P observations (section 2.2). The second step includes the assimilation of the MLS ozone profile to BASCOE (section 2.3), followed by the integration between the tropopause pressure and the top of the atmosphere. In the last step the stratospheric column calculated in resolution of BASCOE $\left(2.5^{\circ} \times 3.75^{\circ} \times 3 \mathrm{~h}\right)$ is interpolated in time and place to match the TROPOMI observations and subtracted from the TROPOMI total columns (section 2.4).

\subsection{TROPOMI Total Ozone Retrieval}

The Sentinel-5 Precursor (S5P) satellite was launched in October 2017 into a sun synchronous orbit with an equator crossing time of 13:30. The TROPospheric Ozone Monitoring Instrument (TROPOMI) observes the atmosphere with a daily coverage and a spatial resolution of $5.5 \times 3.5 \mathrm{~km}^{2}\left(7 \times 3.5 \mathrm{~km}^{2}\right.$ until August 2019) and a spectral resolution of roughly $0.5 \mathrm{~nm}$. The S5P near-real-time total ozone product is based on the well known two step DOAS approach with an iterative Air Mass Factor 
(AMF) calculation (Loyola et al., 2011; Hao et al., 2014). The slant column density is retrieved in the 325 to $335 \mathrm{~nm}$ wavelength range. The S5P cloud algorithm provides cloud top height, cloud optical density and cloud fraction. The innovative approach in S5P is to treat clouds as layers of scattering droplets (Clouds as Layers Loyola et al., 2018). Also in the ozone AMF calculations the same cloud model is applied (Heue et al., 2020a). The surface reflectivity required for the AMF calculation is retrieved from the TROPOMI measurements using a full physics inverse machine learning method (Loyola et al., 2020). Currently the version 2.1.3 of UPAS (Universal Processor for Atmospheric Spectrometers) is being used for generating the S5P NRT total ozone product. Garane et al. (2019) showed that the NRT total ozone column in general agrees well with ground based observations but shows some bias in the polar to midlatitude winter, which was caused by the albedo climatology (Kleipool et al., 2008) used in UPAS version 1.x.

The presented tropospheric algorithm can be applied to the S5P vertical ozone columns retrieved with both NRT and offline algorithm, as well as other satellites. We used the latest version 2.1 of the NRT algorithm and the TROPOMI data were reproccessed internally at DLR.

\subsection{BASCOE Assimilations of Ozone Profiles}

In this work, stratospheric ozone profiles are calculated by the Belgian Assimilation System for Chemical ObsErvations Fast Delivery (BASCOE-FD, through out the manuscript BASCOE and BASCOE-FD are used as synonym) constrained by the Microwave Limb Sounder (MLS) observations. This implementation of BASCOE was developed to prepare the EU Copernicus Atmospheric Monitoring Service (CAMS). BASCOE-FD is based on a chemistry transport model and driven by the analyses of temperature and winds delivered operationally by the European Centre for Medium range Weather Forecast (ECMWF). Since it is an operational service, the BASCOE-FD system has evolved with time due to the changes in the ECMWF operational system, the changes in MLS retrieval algorithm and the changes in the BASCOE system (see the changelog here: http:// www.copernicus-stratosphere.eu/4_NRT_products/3_Models_changelogs/BASCOE.php, Dec. 2021). BASCOE-FD provides analyses of stratospheric ozone and other chemical species operationally with a timeliness of 3-5 days in order to allow the assimilation of the Aura-MLS offline dataset. The BASCOE-FD ozone fields are provided on a $2 .^{\circ}$ latitude by $3.75^{\circ}$ longitude grid with a temporal resolution of 3 hours. Since March 2016, BASCOE-FD uses a vertical grid with 86 levels from the surface to $0.01 \mathrm{hPa}$. An example of the BASCOE-FD ozone mixing ration for 2018-09-18 12:00UTC between 79.6 and $74.1 \mathrm{hPa}$ is shown in Figure 1. Over Antarctica the ozone mixing ratio is reduced, as expected for the austral spring.

An early version of BASCOE-FD has been evaluated against total ozone ground-based measurements, ozonesonde profiles and satellite profiles over the period 2009-2012 (Lefever et al., 2015). The agreement was usually within $+/-10 \%$ but degraded to $+/-40 \%$ in the tropical tropopause layer (TTL). Later evaluations of BASCOE-FD are delivered every three months for the validation of the CAMS operational analyses and indicate biases usually smaller than $5 \%$ in the middle stratosphere and $15 \%$ in the TTL (e.g. Ramonet et al., 2019).

In the upper stratosphere, the BASCOE system has a small ozone deficit (Errera et al., 2019) which introduces a negative bias in the BASCOE-FD stratospheric ozone columns. This has been corrected using a time-latitude climatology of this bias against MLS. This climatology is based on the BASCOE-FD analyses between July 2016 and March 2019 and varies between -1 


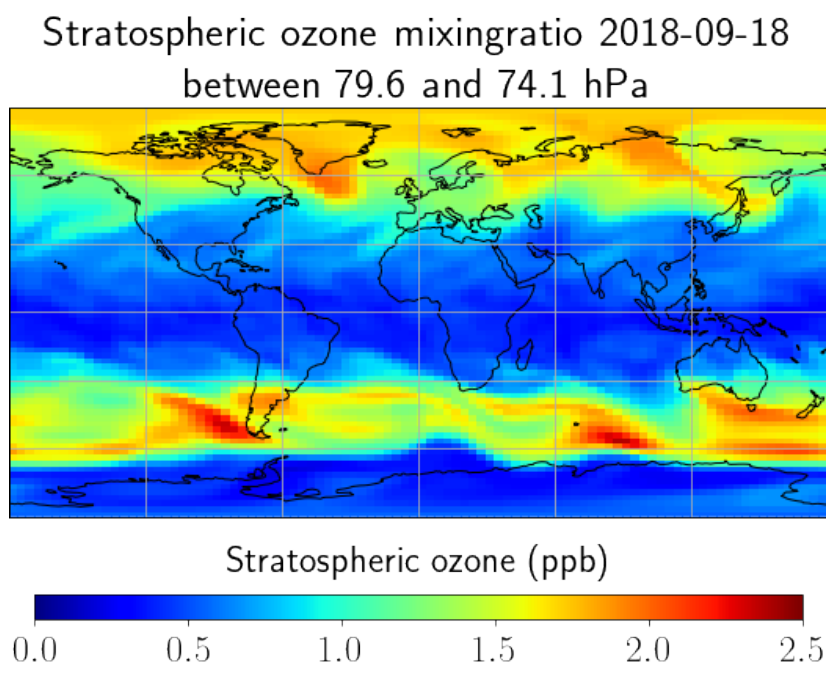

Figure 1. Example of BASCOE $\mathrm{O}_{3}$ mixing ratio for 2018-09-18 12:00 UTC around $76 \mathrm{hPa}$.

and 4 DU (Figure 2). The integration of stratospheric columns from the BASCOE-FD analyses starts at dynamical tropopause height. Outside the tropics it is defined as the Potential Vorticity isosurface at 3.5 PVU and inside the tropics as the isentropic isosurface with a potential temperature of $380 \mathrm{~K}$. The S5P-BASCOE data file contains the corresponding tropopause pressures. In addition, we provide data with alternate Tropopause definitions e.g. 2.5 PVU for the period from August 2019 onwards. The impact of the tropopause definition on the tropospheric ozone column is discussed in section 4.2.

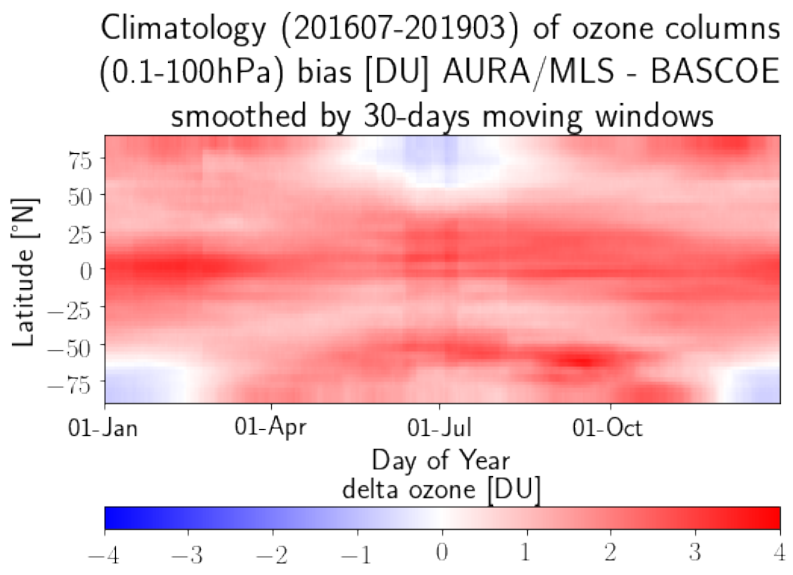

Figure 2. Time-latitude stratospheric ozone column bias climatology between MLS and BASCOE used to correct the BASCOE-FD stratospheric column. 


\subsection{S5P-BASCOE Tropospheric Ozone}

The stratospheric ozone column is calculated from the BASCOE assimilated fields between the tropopause and the upper lid i.e. $0.01 \mathrm{hPa}$. A correction term (Figure 2) accounts for the BASCOE ozone deficit above $4 \mathrm{hPa}$. The latitude and time dependent climatology is added to the stratospheric ozone column, the correction is in the order of $2 \mathrm{DU}$ (section 4). The stratospheric ozone column has the spatial and temporal resolution of 3.75 by 2.5 degree and 3 hours following the resoltion of the BASCOE ozone profile.

TROPOMI/S5P has a daily global coverage with a spatial resolution of $5.5 \times 3.5 \mathrm{~km}^{2}$. The stratospheric ozone column is linearly interpolated in time and space to the TROPOMI pixel centre coordinate and observation time. Figure 3 shows the interpolated stratospheric column for the same day as figure 1, some patterns are similar in the two plots, however the interpolation and vertical integration also cause a significant smoothing.

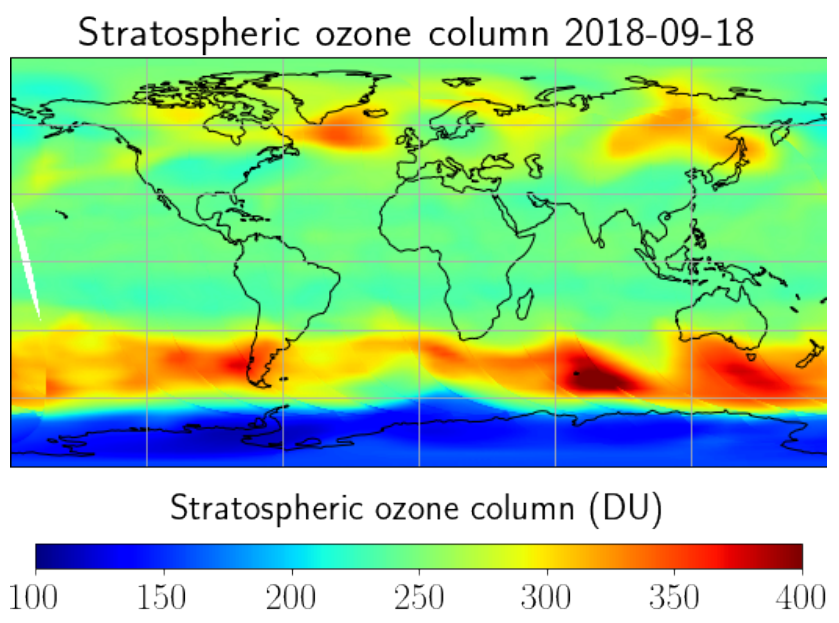

Figure 3. Integrated stratospheric ozone column interpolated to the TROPOMI pixels.

Furthermore, the tropopause pressure as given in the BASCOE results is interpolated to the TROPOMI ground pixels, and stored with the tropospheric column. Clouds shield the lower tropospheric ozone measured by satellite UV-instruments. Because of that we only take TROPOMI observations with a cloud fraction of less than $20 \%$ into account for computing the tropospheric ozone. In the final step the interpolated stratospheric column is subtracted from the total ozone column.

\section{Other tropospheric Data Sets}

\subsection{TROPOMI_CCD}

The tropical tropospheric ozone column based on the convective cloud differential (CCD) algorithm is an official TROPOMI product generated operational and regularly validated, the validation reports are available at http://www.tropomi.eu/documents/ validation (Dec. 2021). The algorithm has been described in a previous publication (Heue et al. , 2016), and the O3_TCL 
ABTD (Heue et al., 2020b) therefore only a short summary is given here. In a reference region $\left(70^{\circ} \mathrm{E}\right.$ to $\left.170^{\circ} \mathrm{W}\right)$ the above cloud column is calculated based on the TROPOMI OFL total ozone column. The OFL total ozone column retrieval uses the GODFIT (GOME Direct FITting) algorithm version 4 as described in Lerot et al. (2010) and used in Inness et al. (2019). During the total column retrieval, a ghost column is added for the part of the ozone column that is shielded by clouds (inside or below the cloud). After subtracting the ghost column the remaining column equals the above cloud ozone.

The mean cloud altitude of the deep convective clouds in the reference regions is close to $10 \mathrm{~km}$, according to the TROPOMI cloud retrieval (Argyrouli et al., 2020) but varies from cloud to cloud. To correct for the different cloud heights a climatology based correction term was introduced, for clouds higher than $10 \mathrm{~km}$ we add a small correction to account for the ozone shielded between $10 \mathrm{~km}$ and the cloud and for lower clouds a respective column is subtracted. Thereby the above cloud columns cover the same altitude range above $10 \mathrm{~km}$. In the mean the correction term is low, because the mean cloud top height is close to the $10 \mathrm{~km}$ level. The cloud altitude corrected above cloud ozone column approximates the stratospheric column. However, the real tropical tropopause is well above $10 \mathrm{~km}$ or $280 \mathrm{hPa}$, the above cloud stratospheric approximation hence also includes the upper troposphere.

It is assumed that the for certain latitude bands the stratospheric ozone column is constant in time and along the longitude. This assumption is only justified within the tropics, therefore the algorithm is limited to the latitude range between $20^{\circ} \mathrm{S}$ and $20^{\circ} \mathrm{N}$.

We subtract the stratospheric ozone column from total ozone column for the cloud free observations (cloud fraction less than $10 \%)$. The cloud free data are averaged within a certain latitude $\mathrm{x}$ longitude grid and a time period. Compared to the previous version of the CCD data set published within ESA?s ozone CCI the spatial resolution was adapted to $0.5^{\circ}$ latitude $\mathrm{x}$ $1^{\circ}$ longitude. The temporal resolution for the CCI data set from GOME-2B and OMI is one month, with TROPOMI it is now reduced to 6 days for the stratospheric column and 3 days for the tropospheric column. Due to the latitudinal limitations of the CCD method the comparison between the two S5P tropospheric ozone datasets can be performed only within the tropics. The different altitude ranges from the surface to $280 \mathrm{hPa}$ for CCD or to the $380 \mathrm{~K}$ level 80 to $130 \mathrm{hPa}$ for S5P-BASCOE causes a systematic difference. For the following comparison (section 4) we added a correction column to the CCD data based on the ozone profile by McPeters and Labow (2012) to reduce this bias.

\subsection{OMPS-MERRA-2 tropospheric ozone}

170 The evaluation of TROPOMI/BASCOE tropospheric ozone includes comparisons with a research product of tropospheric column ozone derived by combining total column ozone from the Suomi National Polar orbiting Partnership (NPP) Ozone Mapping Profiler Suite (OMPS) nadir-mapper (NM) with stratospheric column ozone from Modern-Era Retrospective analysis for Research and Applications-2 (MERRA-2). Daily global maps of OMPS-MERRA-2 tropospheric column ozone were determined using a residual method similar to Ziemke et al. (2006) that subtracts stratospheric column ozone from total column ozone.

The OMPS-NM instrument measures total column ozone about three minutes from TROPOMI overpass, providing an ideal dataset for cross-comparisons with TROPOMI. Total ozone from OMPS is determined using a version 2.1 algorithm that in- 
cludes aerosol adjustments and cloud optical centroid pressures (OCPs) in the retrievals (McPeters et al., 2017). The OMPS data including quality evaluation are available from https://ozoneaq.gsfc.nasa.gov/data/omps/(Jan. 2022). The OMPS-NM provides full global coverage of the sunlit Earth each day, making 400 scans per orbit with 36 across-track measurements for each scan. OMPS field of view (FOV) is about $50 \mathrm{~km}$ by $50 \mathrm{~km}$ at nadir and about $250 \mathrm{~km}$ by $250 \mathrm{~km}$ at high track position. The MERRA-2 data assimilation system (Gelaro et al., 2017) uses Aura OMI v8.5 total ozone and MLS v4.2 stratospheric ozone profiles to produce global synoptic maps of profile ozone from the surface to the top of the atmosphere; these profiles are reported every three hours $(0,3,6, ?, 21 \mathrm{UTC})$ at a resolution of $0.625^{\circ}$ longitude $\mathrm{x} 0.5^{\circ}$ latitude. For each hourly map and at each grid-point, MERRA-2 profile ozone was integrated vertically from the top of the atmosphere down to tropopause pressure to derive maps of stratospheric column ozone. Tropopause pressure was determined from MERRA-2 re-analyses using standard PV- $\Theta$ definition (2.5 PVU and 380K). The resulting maps of stratospheric column ozone from MERRA-2 were then co-located and subtracted from OMPS total ozone, thus producing daily global maps of tropospheric column ozone sampled at OMPS local time. These tropospheric ozone pixel measurements were binned to $1^{\circ}$ latitude $\mathrm{x} 1^{\circ}$ longitude resolution. In the following the dataset will be named OMPS-MERRA-2. MERRA-2 assimilated stratosphere column ozone was found to agree within $\pm 2-3$ DU with the collocated MLS measurements. Comparisons between collocated ozone sonde and OMPS-MERRA2 tropospheric column ozone in the tropics and extra-tropics indicate mean differences varying from near zero to at most $\approx \pm 6$ DU, and standard deviations from a few DU to at most $\approx 6-8$ DU. Largest differences and standard deviations were found in the mid- and high latitudes with smaller biases in the tropics. The OMPS-MERRA-2 tropospheric ozone columns were not filtered for clouds. There were no adjustments of any kind applied to the OMPS-MERRA-2 tropospheric column ozone.

In contrast to the CCD data, the OMPS-MLS tropospheric data provide a global data set for the comparison. However, the analysis approach is similar to the one presented here, in particular both use MLS data for quantifying the stratospheric contribution. Therefore, the following comparison is not based on fully independent data sets.

\subsection{Ozone sondes}

Ozone sondes are regularly launched from various stations around the globe. The data are provided by the national services and can be downloaded via World Ozone and Ultraviolet Radiation Data Centre (https://woudc.org/data/dataset_info.php?id= ozonesonde, Nov. 2021). The sounding stations are globally distributed. For this comparison we considered sounding data from more than 60 soundings stations. However, some stations launch a balloon every week other once in a month. Also the spatial distribution is not uniform, while 7 stations in Europe provided roughly 600 soundings in 2018 and 2019 there were only one sounding station in China (Hong-Kong $\approx 140$ soundings and one for the US mainland in Boulder (CO) with about 120 profiles.

\section{Comparison to Tropospheric Ozone Observations}

Our S5P-BASCOE tropospheric ozone data are compared to the data sets presented in section 3. For the S5P CCD (OFL-O 3 ) and S5P-BASCOE $\left(\mathrm{NRT}-\mathrm{O}_{3}\right)$ the total ozone columns are observed with the same instrument but are retrieved using different algorithmns. OMPS-MERRA-2 and S5P-BASCOE share not only the similar retrieval approach but additionally BASCOE 

independent measurements. The ozone sondes however are an independent and widely accepted validation data set.

Both S5P_CCD and OMPS-MERRA-2 are gridded dataset with resolution of $0.5^{\circ} \times 1^{\circ}$ and $1^{\circ} \times 1^{\circ}$ latitude by longitude, respectively. For the comparisons the S5P-BASCOE data set is first gridded to $0.25^{\circ} \times 0.25^{\circ}$ and averaged to match the grid cells of the S5P_CCD and the OMPS-MLS datasets.

\subsection{Comparison to S5P_CCD}

The tropical tropospheric ozone column retrieval (S5P_CCD) is described in section 3.1. The data are restricted to the inner tropical range between $20^{\circ}$ South and $20^{\circ}$ North and include the vertical range up to $280 \mathrm{hPa}$. We use the same time period as for OMPS-MERRA-2 (sect. 4.2) from April 2018 to June 2020. The monthly difference for April 2018 (Figure 4) shows that the difference is mostly negative, S5P-BASCOE is lower than S5P_CCD, but the differences are typically less than 5 DU. There is no systematic structure like land-sea bias to be found in the plots. The stripe in the south is caused by a well known and documented retrieval problem in the CCD data. The time series of the tropical averaged difference between S5P-BASCOE and S5P_CCD is illustrated in Figure 5. The figure also includes a comparison to the OMPS-MERRA-2 tropospheric column which will be discussed in more detail in section 4.2. The daily averaged tropical differences to the CCD also show a negative bias and variability of about 4 DU. In June / July 2018 three peaks are found in the difference plot. A similar but smaller pattern can be seen in the comparison to OMPS-MERRA-2. During these periods S5P-BASCOE data seems to overestimate the maximum over the Atlantic Ocean for these periods compared to S5P_CCD.

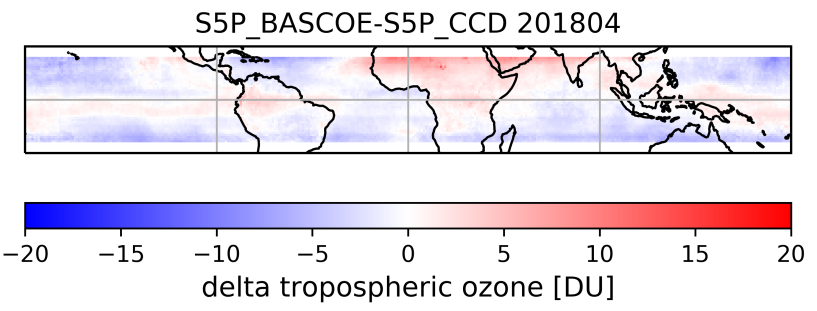

Figure 4. Monthly mean difference between S5P-BASCOE and S5P_CCD for April 2018.

\subsection{Comparison to OMPS-MERRA-2}

Tropospheric ozone columns from OMPS-MERRA-2 are described in section 3.2. The mean difference for May 2020 (Figure 6) shows an underestimation around $20^{\circ}$ North especially over the Saharan dessert and an overestimation in the northern mid to high latitudes as well as in the southern high latitudes. This pattern is typical also for the other month included in this comparing exercise. In the mean an overestimation can be found, but for large parts of the world the differences are smaller than \pm 5 DU. 


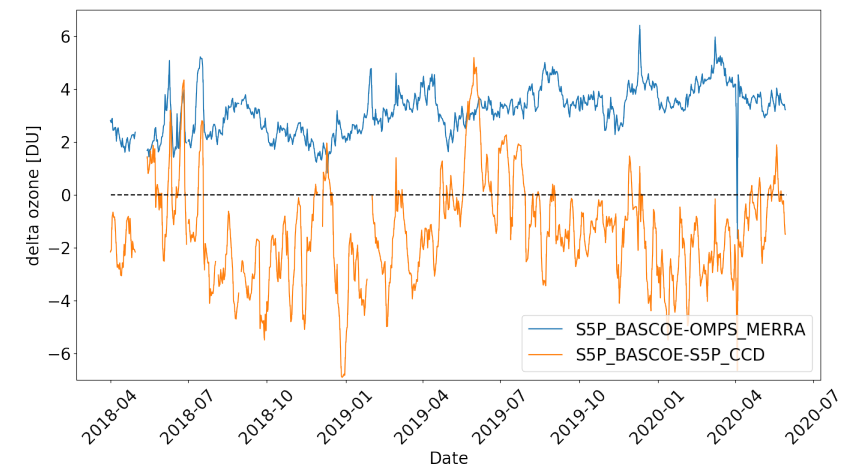

Figure 5. Time series of the differences between S5P-BASCOE and S5P_CCD (orange) and OMPS-MERRA-2 (blue). The CCD comparison focuses on the tropical region while for the OMPS-MERRA-2 the global data sets were considered. In the temporal mean a negative bias $(\approx 2 \mathrm{DU})$ is found relative to $\mathrm{CCD}$ data and a positive one $(\approx 3 \mathrm{DU})$ relative to OMPS-MERRA-2.
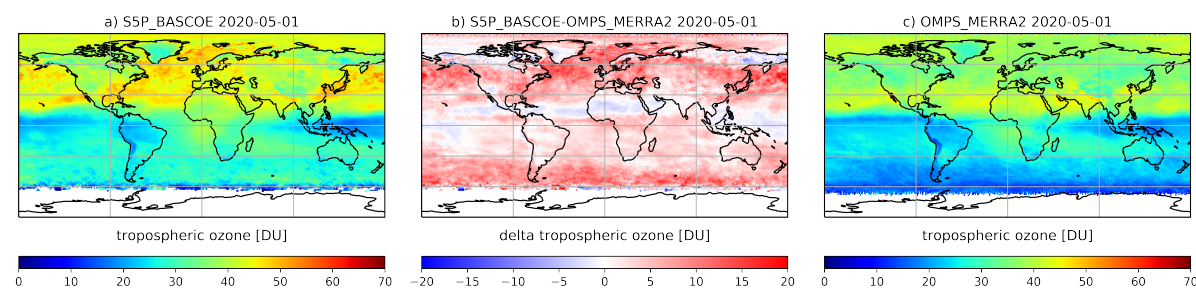

Figure 6. Monthly mean tropospheric ozone columns for May 2020 as observed by S5P-BASCOE (a) and OMPS-MERRA-2 (c), and the difference between the two data sets (b).

The globally averaged difference between S5P-BASCOE and OMPS-MERRA-2 for each day is shown in Figure 5 together with the differences to the CCD based tropospheric ozone. The differences vary between 2 and $6 \mathrm{DU}$ with a mean difference of 3-4 DU. Garane et al. (2019) showed that the TROPOMI NRT total ozone column is overestimated by $1 \%$ or 4DU relative to Brewer and Dobson spectrometers. Compared to OMPS we can find a similar deviation in the total columns (not shown). Therefore the deviation in the tropospheric ozone column in a similar order of magnitude is to be expected. The time series of both tropospheric ozone products S5P-BASCOE and OMPS-MERRA-2 (not shown), reveal that the three peaks in June and July 2018 are partly caused by a decrease in the OMPS-MERRA-2 data set and to some extent by an increase in the S5PBASCOE data. The different stratospheric ozone models BASCOE-FD (Sec. 2.3) and MERRA-2 (Sec. 3.2) are both constraint by MLS ozone profile observations. Nevertheless, some differences can be found. For BASCOE a small ozone deficit is known and corrected for. The correction in Figure 2 ranges between -1 and 3 DU, in the mean it contributes 1 DU to the stratospheric column. For the tropospheric columns this causes a corresponding reduction.

In BASCOE the tropopause level is given as the lowest layer with a PV value higher than 3.5 PVU, whereas in MERRA-2 the 2.5 PVU level is used. Within the tropics, where differences between the two tropospheric column data sets are smallest, both BASCOE and MERRA-2 use the $380 \mathrm{~K}$ potential temperature definition. For the BASCOE data after August 1 also the 


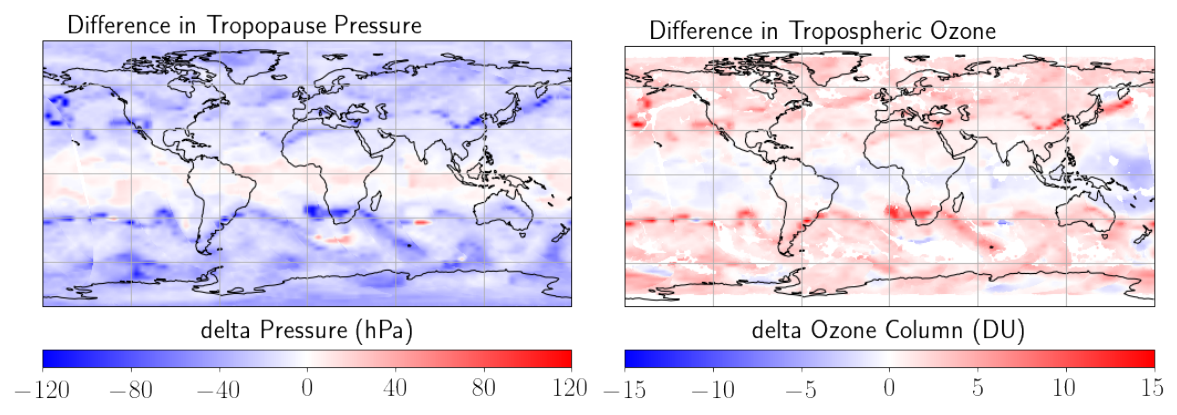

Figure 7. Difference in the tropopause pressure (left) and tropospheric ozone columns caused by the different definitions of the tropopause level. For both figures the data according to 2.5 PVU level is subtracted from the related data for the 3.5 PVU level. The cloud filter was adapted to avoid the respective data gaps.

2.5 PVU pressure is given in addition to standard definition. This can be used to calculate the difference cause by the different tropopause definitions, an example for September 252019 is shown in figure 7. In the tropics the $380 \mathrm{~K}$ level is used, however a small difference in the definitions might cause the differences in both pressure and tropospheric ozone. Traditionally the tropopause is given as the centre of the pressure level containing the $3.5 \mathrm{PVU}$ or $380 \mathrm{~K}$ level, for the comparison the 2.5 PVU/ $380 \mathrm{~K}$ pressure level was used directly. The influence of the different tropopause definitions on the tropospheric ozone is about 1-2 DU and might therefore explain at least half of the differences between our data set and OPMS-MERRA-2. Moreover, the general pattern of the difference agrees well with the pattern observed in Figure 6. Both figures show a negative deviation in the tropics and positive one in mid-latitude, although Figure 6 shows a monthly mean and Figure 7 is an example day.

\subsection{Comparison to Sonde}

We compare the ozone sonde date for the period April 2018 to October 2020 with collocated satellite observations. We assume data to be collocated if the sounding was on the same day and the distance between the sounding station and the satellite observation was less than $100 \mathrm{~km}$. The sonde data are integrated from the ground level to tropopause given as mean tropopause pressure within the $100 \mathrm{~km}$ radius. We have to be aware that within $100 \mathrm{~km}$ radius the surrounding may be heterogeneous with respect to urban and rural areas or mountains (Figure 8) or sea.

Some stations also provide total column data form Brewer or Dobson instruments situated next to the sounding station. This allows us to compare both tropospheric ozone up to the mean tropopause pressure and the total column and potential deviations might be separated.

For the sonde validation shown in Figure 9 a slight overstimation in the winter / spring season is observed. In version 2 of UPAS a new albedo retrieval scheme was implemented (Loyola et al., 2020) and respective comparison improved significantly. The deviation in the total columns due to the albedo is already documented by Inness et al. (2019) and Garane et al. (2019). Compared to the ground-based observations TROPOMI total ozone columns are slightly overestimated also in the summer month when the snow ice issue is not that significant. This deviation propagates into the tropospheric column, at least 


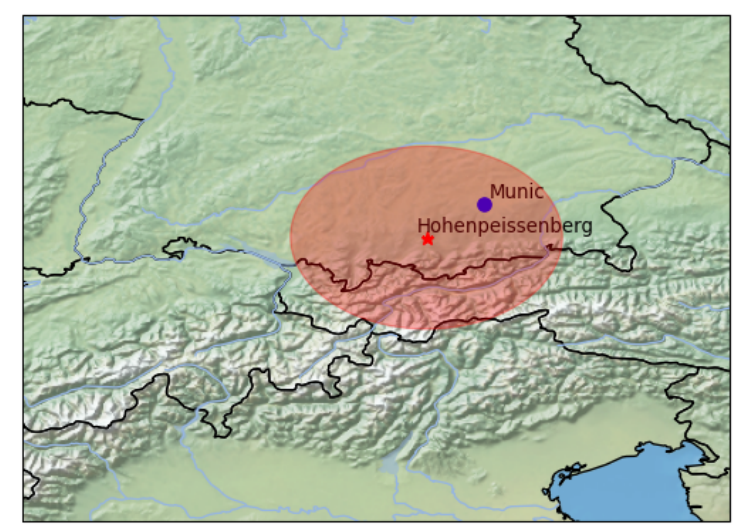

Figure 8. Southern Germany and the Alps including the location of the Hohenpeißenberg sounding station and a circle of $100 \mathrm{~km}$ to illustrate the size of the area sampled by the satellite. In this case both urban (Munich) and alpine regions are included in the $100 \mathrm{~km}$ radius. Due to the projection the circle is slightly distorted. Made with Natural Earth. Free vector and raster map data at naturalearthdata.com (Jan 2022).

for parts of the year. On the other hand there might also be an understimation in the sonde data as W. Steinbrecht (DWDHohenpeißenberg) pointed out during the CEOS Atmospheric Composition Virtual Constellation Conference in June 2021. The ozone effective temperature is not considered in the Dobson spectrometer observations and the sonde data are scaled to the Dobson total ozone column.

The mean deviation per $10^{\circ}$ latitude band (Figure 10) also shows a small positive bias, both in the tropics and the mid latitudes. The deviation increases towards the poles, especially for the comparison between $70^{\circ}$ and $80^{\circ}$ north. Similarly for the southern polar region a systematic bias in the total ozone column was found. Which was partly caused by the above mentioned albedo uncertainty. However, the bias is smaller here and for the tropospheric ozone columns it seems even less. The comparisons in the polar regions have to be taken with care, due to the sparse sampling in time and space, the comparison is certainly not representative. A small positive bias $(\leq 5 \mathrm{DU})$ relative to the sonde data is found for tropical to midlatitudes

\section{Results}

In the prevoius sections we introduced a new TROPOMI/S5P tropospheric ozone product and compared it to similar satellite products as well as to integrated ozone sondes measurements. In the following we will discuss the tropospheric ozone columns for some specific regions.

\subsection{Global Tropospheric Ozone Distribution}

Figure 11 shows the global tropospheric ozone distribution for week of 2018-07-02 until 2018-07-08 . During the northern hemispheric summer typical three major enhancements can be seen: South Eastern US, Eastern Mediterranean and North Eastern China. In the tropics the typical wave one-pattern is found, showing the global minimum in the Pacific Ocean north of 


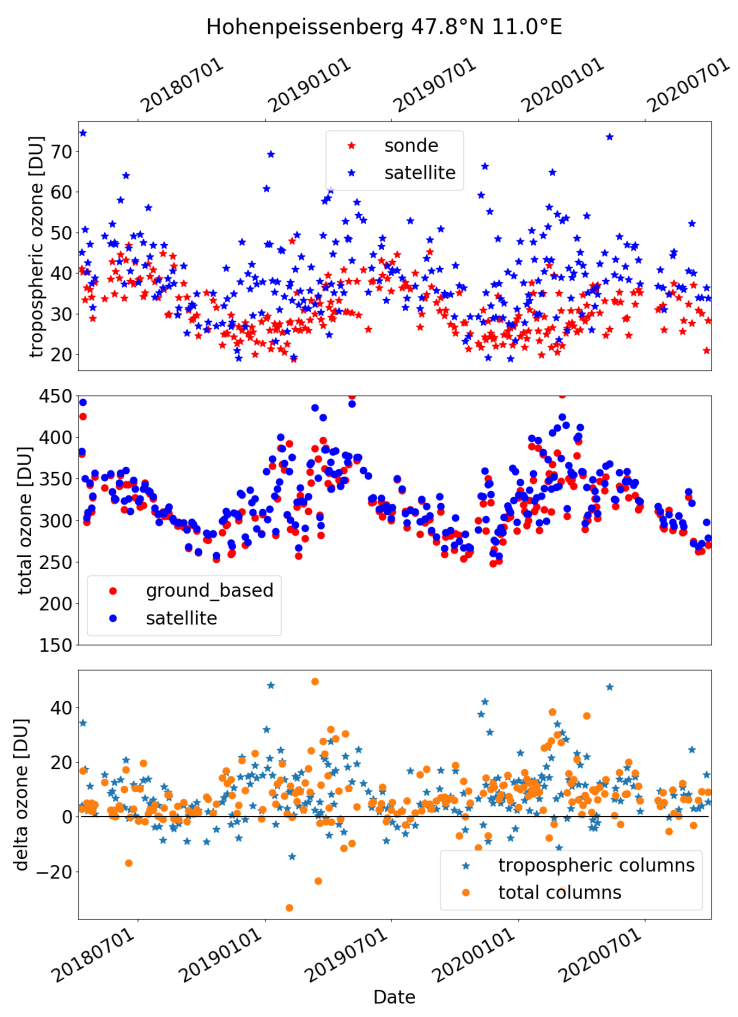

Figure 9. Comparison of S5P-BASCOE the tropospheric ozone columns with ozone sondes at Hohenpeißenberg. On top the tropospheric columns are compared to the integrated sonde measurements. In the centre the total ozone columns are compared, finally at the bottom the differences between the satellite data and the integrated sondes is shown.

New Guinea and the maximum is in the central Atlantic Ocean close to the central African coast. In the southern hemisphere no significant structure is found in the austral winter.

Whether the enhanced ozone columns over the Northern Pacific Ocean between China, Japan and Alaska as well as over the Atlantic Ocean from the Iberian Peninsula westward are caused by transport phenomena has to be investigated in future studies.

\subsection{Africa and tropical Atlantic}

Biomass burning emits both VOCs and NOx which are the main precursors of tropospheric ozone. Africa contributes about half of the total biomass burning carbon emissions (e.g. Pan 2019). The local burning seasons moves north and south following the ITCZ, with a time shift of 6 months. The tropospheric ozone columns follow the burning season pattern. Therefore in June-July, when the ITCZ reaches the northern most point the burning season is south of the Equator (Figure 12), the massive fires cause a large ozone plume reaching several hundreds of km out over the Atlantic ocean. 


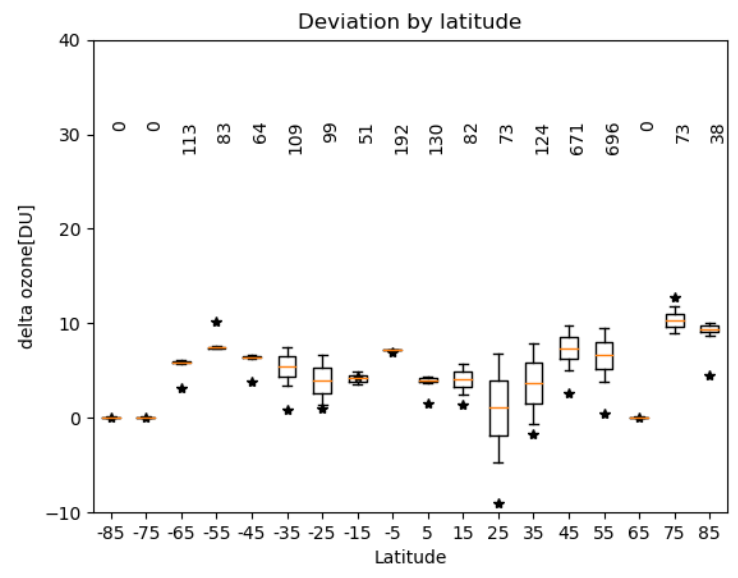

Figure 10. Mean deviations between S5P-BASCOE and the sonde data for $10^{\circ}$ latitude bands and the time period between April 2018 and October 2020. The stars indicate the mean of the tropospheric observations closest to the stations. The red line indicates the $100 \mathrm{~km}$ radius mean and the box and the lines represent 1 and 2 standard deviations. The numbers on top give the amount of comparisons per latitude band.

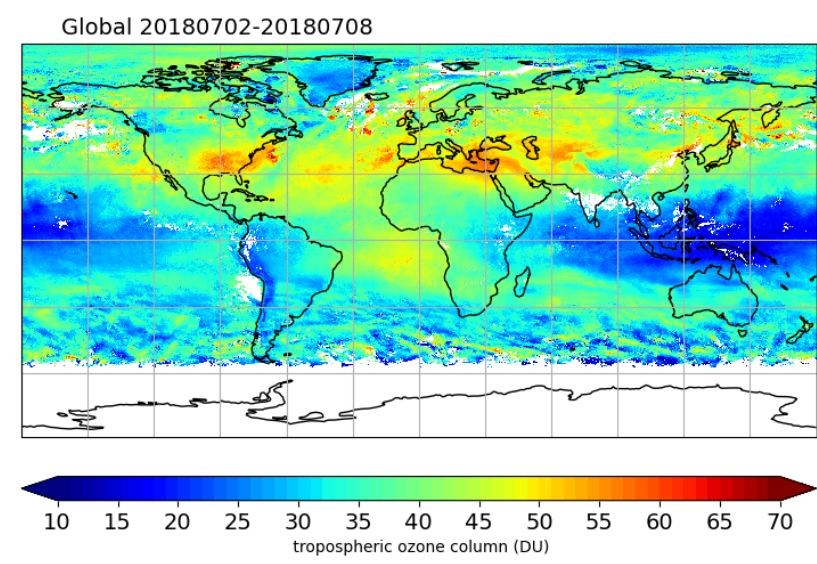

Figure 11. Global distribution of the mean tropospheric ozone for the first week of July 2018.

\subsection{Europe and the Mediterranean}

The people living around the Eastern Mediterranean regularly suffer from high ozone concentration in summer (e.g. Dayan et al., 2017).

The time series of tropospheric ozone columns over the Greece capital of Athens (Figure 13) shows enhanced values for the summer 2018 and 2019 reaching up to 80 DU. In July and August (both 2018 and 2019) several days of high column density are observed, the lowest values are still well above 40 to 50 DU. Enhanced column density are also found through out the years, but especially in spring the column density often decreases rapidly after a few days. Such a dercrease is hardly observed in 


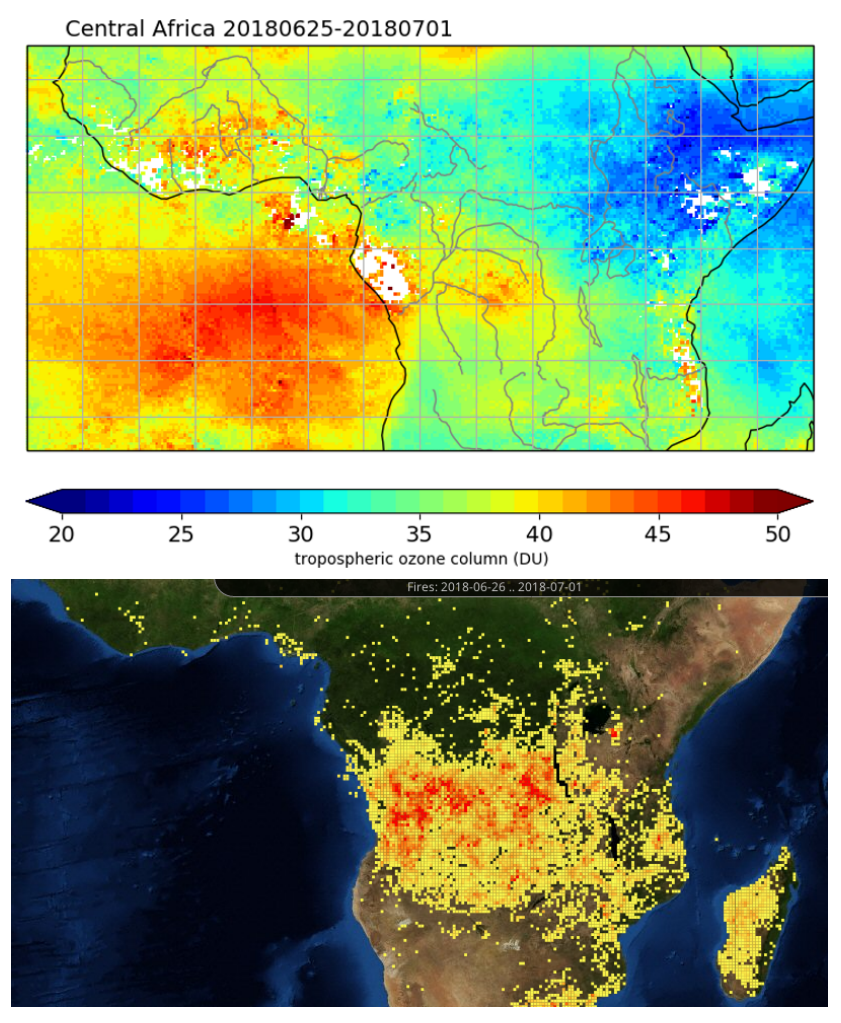

Figure 12. Tropospheric ozone columns (left) over Central Africa for late June 2018 and the fire counts for the same period https://firms. modaps.eosdis.nasa.gov/, Jan. 2022.

summer. Similar time series can be found at several places around the Eastern Mediterranean, indicating stable conditions for a longer period. According to Figure 11 the high ozone values reach from the Eastern Mediterranean to the Persian Gulf. The summer 2019 was extremely dry in northern Germany and large parts of Europe and the weather was stable for a week or two (https://www.dwd.de/DE/wetter/thema_des_tages/2019/12/21.html, Jan. 2022). However, the time series for Berlin (Figure 13) still shows lower tropospheric columns and higher variation in the tropospheric ozone column as in Athens.

\subsection{Southern United States}

In the South West of the United States high ozone columns are observed in summer. The observed tropospheric ozone columns over the United States are shown in Figure 14. High tropospheric ozone columns are found east of $100^{\circ}$ West, this correlates very well with the enhanced formaldehyde (HCHO) columns as observed by S5P (de Smedt et al., 2018). Formaldehyde can be used as tracers for VOCs as tropospheric ozone precursors. The maximum in the tropospheric ozone is shifted to the east compared to formaldehyde. Due to longer lifetime of ozone the tropospheric ozone is transported to the north east and over the Atlantic Ocean. A similar pattern is observed over California; here the maximum of the tropospheric column is clearly separated from the $\mathrm{HCHO}$ enhancements. 
https://doi.org/10.5194/amt-2022-23

Preprint. Discussion started: 17 February 2022

(c) Author(s) 2022. CC BY 4.0 License.

(c) (1)

\section{Atmospheric Measurement Techniques}

Discussions
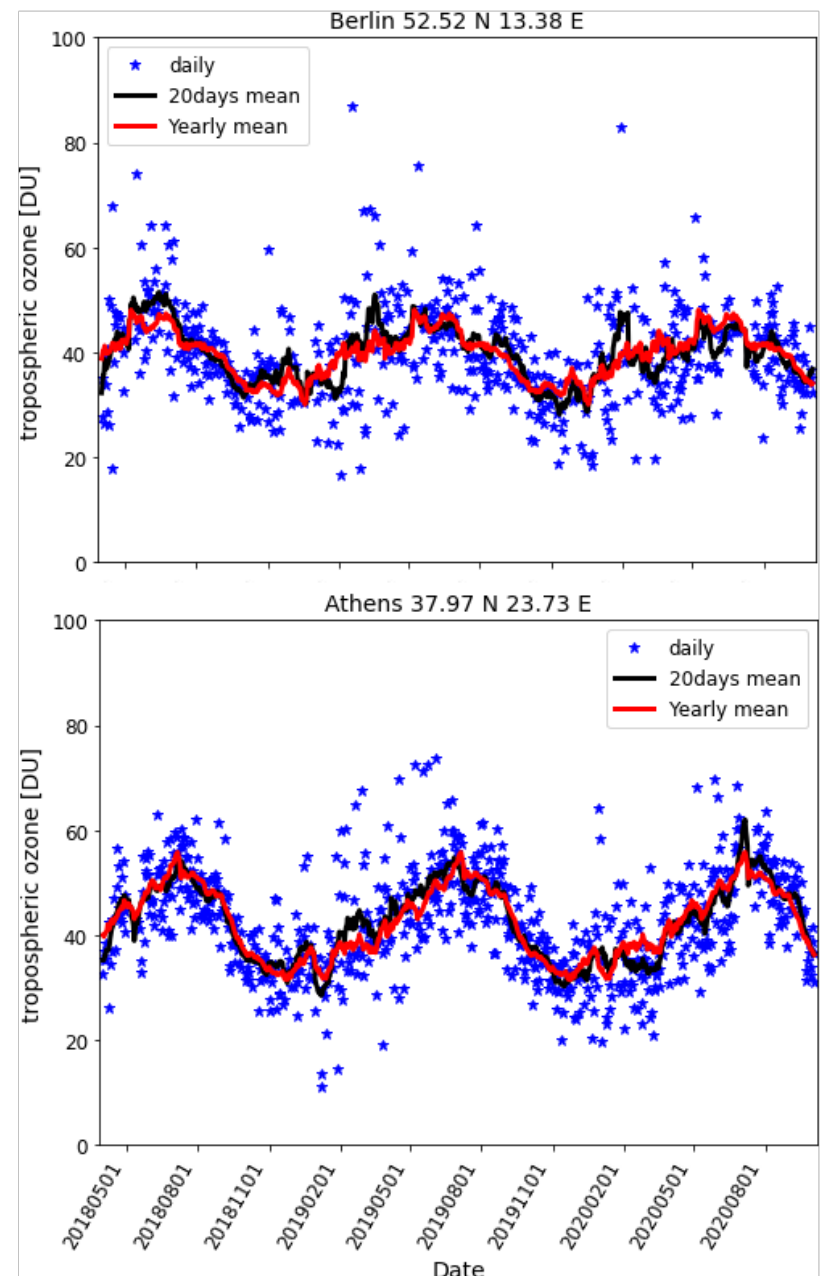

Figure 13. S5P-BASCOE tropospheric ozone column over Athens (Greece) and Berlin (Germany) (50 km radius around the centre). The time series shows clear maxima in summer and minima in winter as expected. The blue stars indicate daily observations, while the black line is the 20 days running mean, for comparison between the different years the typical annual cycle in red is included based on the 20 days running mean.

\section{Conclusions}

We presented a new tropospheric ozone dataset based on Sentinel 5P/TROPOMI total ozone columns in combination with

BASCOE stratospheric columns. The S5P-BASCOE tropospheric columns have the high TROPOMI spatial resolution of 3.5 x $5.5 \mathrm{~km}^{2}$. Except for small bias, originating from the total columns, the data are in good agreement with the tropospheric 


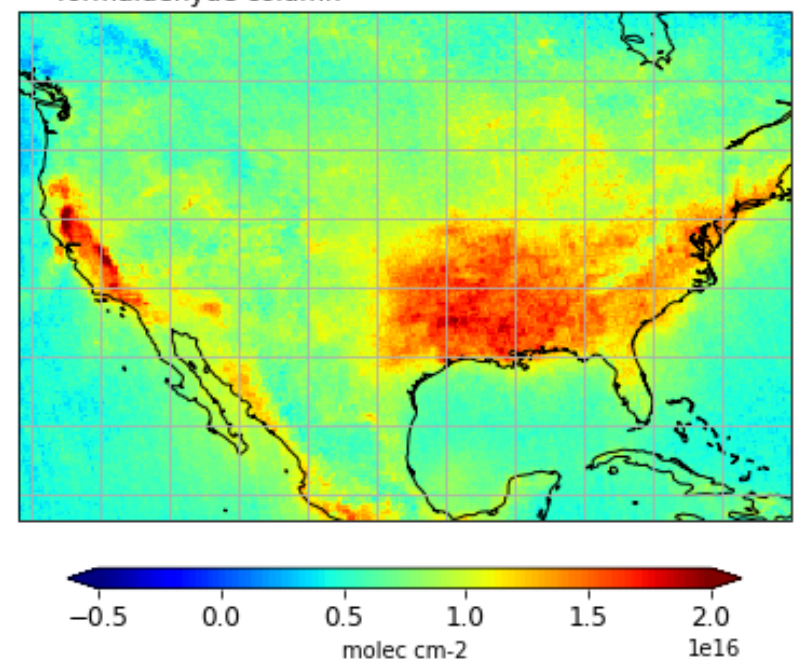

tropospheric ozone column

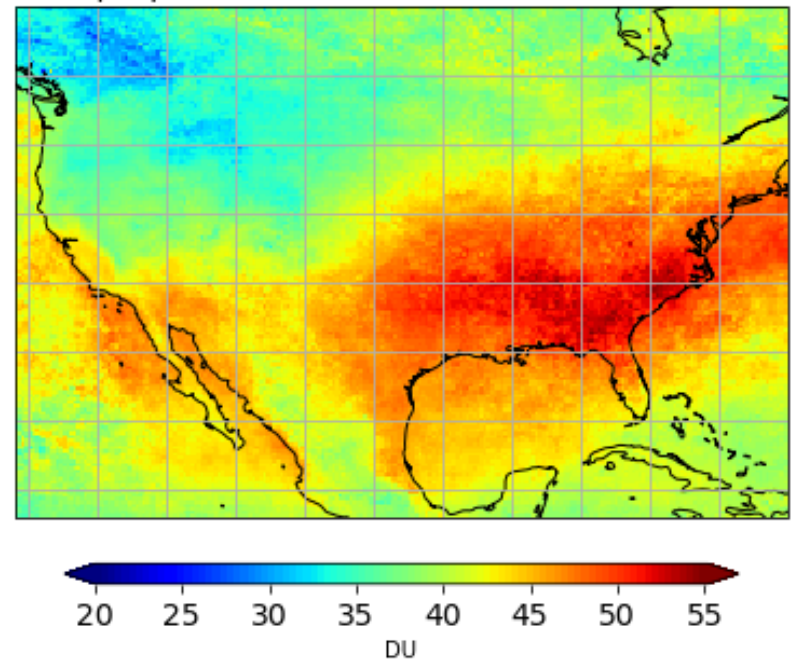

Figure 14. Formaldehyde (top) and tropospheric ozone (bottom) over the United States observed in July 2018. Formaldehyde is a tropospheric ozone precursors.

ozone data based on OMPS/MERRA-2. S5P_CCD and S5P-BASCOE cover a different altitude range. For the comparison we added a correction column based on a climatology to the CCD data. The agreement between S5P-BASCOE and the S5P_CCD data product is reasonable. The variability in the difference between S5P-BASCOE and S5P_CCD is higher compared to S5PBASCOE minus OMPS-MERRA-2. This indicates that the difference is to large extend given by the stratospheric columns. The algorithms of OMPS-MERRA-2 and S5P-BASCOE are very similar, while the S5P_CCD data are retrieved using a completely different approach. The comparison to the ozone sondes showed a slight positive bias as well as for the OMPS/MERRA-2 2 , 
which is probably caused by a small overestimation in the total column data. The comaprison to the sonde data also showed a positive bias, which in parts be attributed to both the S5P-BASOE and the sondes.

We plan to apply the same algorithms to past and current nadir sattelite ozone observations from GOME-2 and OMI, as well as the future Sentinel 4 and 5 missions. With this longer time series changes in the tropospheric ozone columns induced by longterm trends or atmospheric compositions changes as a consequence of the COVID19 lockdown measures might be investigated on a global scale.

The S5P-BASCOE tropospheric ozone columns showed the expected global distribution. In the tropics the wave one pattern is found and can at least partly be attributed to biomass burning in central Africa. During the northern hemispheric summer, the tropospheric ozone increases over the eastern Mediterranean or the South East of the United States. Some ozone enhancements over the Atlantic ocean might be attributed to medium range transport.

Author contributions. This work is only possible within a team. Klaus-Peter Heue developed the S5P tropospheric ozone algorithms presented here and prepare this paper. Diego Loyola initiated this study and supported it with numerous discussions; he contributed to this paper through various helpful comments. Walter Zimmer and Fabian Romahn are responsible for operational implementation of the Sentinel 5P total ozone retrieval, the CCD retrieval and the S5P cloud retrieval. Simon Chabrillat, Quentin Errera and Yves Christophe provide the BASCOE ozone profile data and prepared the respective section in the manuscript. Jerry Ziemke and Natalya Kramarova provided the OMPS-MERRA-2 tropospheric data and wrote the OMPS-MERRA-2 section.

Competing interests. The authors have the following competing interests: At least one of the (co-)authors is a member of the editorial board of Atmospheric Measurement Techniques.

Acknowledgements. Thanks to Yves Christophe (retired from BIRA-IASB) for setting up the operational process of MLS assimilation by the BASCOE system. We gratefully acknowledge all ozone sonde data providers for providing the $\mathrm{O}_{3}$ profiles used in this manuscript: WMO/GAW Ozone Monitoring Community, World Meteorological Organization-Global Atmosphere Watch Program (WMO-GAW)/World Ozone and Ultraviolet Radiation Data Centre (WOUDC) [Sonde]. Retrieved October 20, 2019, from https://woudc.org,Dec2021. A list of all contributors is available on the website. doi:10.14287/10000001. We thank NOAA for providing the ozone sonde data from Boulder (ftp://aftp.cmdl.noaa.gov/data/ozwv/Ozonesonde/Boulder_Colorado, Dec 2021). Thanks to EU/ESA/DLR for providing the operational TROPOMI/S5P products used in this paper: total ozone, CCD tropospheric ozone and cloud properties. We acknowledge the use of data and/or imagery from NASA's Fire Information for Resource Management System (FIRMS) (https://earthdata.nasa.gov/firms), part of NASA's Earth Observing System Data and Information System (EOSDIS). 
Ainsworth, E. A., Yendrek C.R., Sitch S., Collins, W. J. and Emberson, L. D.: The Effects of Tropospheric Ozone on Net Primary Productivity and Implications for Climate Change Annual Review of Plant Biology 2012 63:1, 637-661, doi: 10.1146/annurev-arplant-042110-103829, 2012.

Argyrouli, A., Loyola, D., Lutz, R., Spurr,R. :S5P/TROPOMI ATBD cloud products, S5P-DLR-L2-400I, V2.1 issue: 2.1; Feb. 2020 available at: http://www.tropomi.eu/documents/atbd

Avnery, S., Mauzerall, D. L., Liu, J. and Horowitz, L. W.: Global crop yield reductions due to surface ozone exposure: 1 . Year 2000 crop production losses and economic damage, Atmospheric Environment, 45, 13, 2284-2296, doi: 10.1016/j.atmosenv.2010.11.045, 2011.

Boynard, A., Hurtmans, D., Garane, K., Goutail, F., Hadji-Lazaro, J., Koukouli, M. E., Wespes, C., Vigouroux, C., Keppens, A., Pommereau, J.-P., Pazmino, A., Balis, D., Loyola, D., Valks, P., Sussmann, R., Smale, D., Coheur, P.-F., and Clerbaux, C.: Validation of the IASI FORLI/EUMETSAT ozone products using satellite (GOME-2), ground-based (Brewer-Dobson, SAOZ, FTIR) and ozonesonde measurements, Atmos. Meas. Tech., 11, 5125-5152, https://doi.org/10.5194/amt-11-5125-2018, 2018.

Cuesta, J., Eremenko, M., Liu, X., Dufour, G., Cai, Z., H?pfner, M., von Clarmann, T., Sellitto, P., Foret, G., Gaubert, B., Beekmann, M., Orphal, J., Chance, K., Spurr, R., and Flaud, J.-M.: Satellite observation of lowermost tropospheric ozone by multispectral synergism of IASI thermal infrared and GOME-2 ultraviolet measurements over Europe, Atmos. Chem. Phys., 13, 9675-9693, doi: 10.5194/acp-139675-2013, 2013.

Cooper, O.R., Parrish, D.D., Ziemke, J., Balashov, N.V., Cupeiro, M., Galbally, I.E., Gilge, S., Horowitz, L., Jensen, N.R., Lamarque, J.-F., Naik, V., Oltmans, S.J., Schwab, J., Shindell, D.T., Thompson, A.M., Thouret, V., Wang, Y. and Zbinden, R.M.: Global distribution and trends of tropospheric ozone: An observation-based review. Elem Sci Anth, 2, p.000029. DOI: 10.12952/journal.elementa.000029, 2014.

Dayan, U., Ricaud, P., Zbinden, R., and Dulac, F.: Atmospheric pollution over the eastern Mediterranean during summer - a review, Atmos. Chem. Phys., 17, 13233-13263, doi: 10.5194/acp-17-13233-2017, 2017

De Smedt, I., Theys, N., Yu, H., Danckaert, T., Lerot, C., Compernolle, S., Van Roozendael, M., Richter, A., Hilboll, A., Peters, E., Pedergnana, M., Loyola, D., Beirle, S., Wagner, T., Eskes, H., van Geffen, J., Boersma, K. F., and Veefkind, P.: Algorithm theoretical baseline for formaldehyde retrievals from S5P TROPOMI and from the QA4ECV project, Atmos. Meas. Tech., 11, 2395-2426, doi: 10.5194/amt11-2395-2018, 2018.

Ebojie, F., von Savigny, C., Ladstätter-Weißenmayer, A., Rozanov, A., Weber, M., Eichmann, K.-U., Bötel, S., Rahpoe, N., Bovesmann, H., and Burrows, J. P.: Tropospheric column amount of ozone retrieved from SCIAMACHY limb?nadir-matching observations, Atmos. Meas. Tech., 7, 2073?2096, https://doi.org/10.5194/amt-7-2073-2014, 2014.

Errera, Q., Chabrillat, S., Christophe, Y., Debosscher, J., Hubert, D., Lahoz, W., Santee, M. L., Shiotani, M., Skachko, S., von Clarmann, T., and Walker, K.: Technical note: Reanalysis of Aura MLS chemical observations, Atmos. Chem. Phys., 19, 13647-13679, https://doi.org/10.5194/acp-19-13647-2019, 2019.

Fleming, Z.L., Doherty, R.M., von Schneidemesser, E., Malley, C.S., Cooper, O.R., Pinto, J.P., Colette, A., Xu, X., Simpson, D., Schultz, M.G., Lefohn, A.S., Hamad, S., Moolla, R., Solberg, S. and Feng, Z., 2018. Tropospheric Ozone Assessment Report: Present-day ozone distribution and trends relevant to human health. Elem Sci Anth, 6(1), p.12. DOI: 10.1525/elementa.273

Garane, K., Koukouli, M.-E., Verhoelst, T., Lerot, C., Heue, K.-P., Fioletov, V., Balis, D., Bais, A., Bazureau, A., Dehn, A., Goutail, F., Granville, J., Griffin, D., Hubert, D., Keppens, A., Lambert, J.-C., Loyola, D., McLinden, C., Pazmino, A., Pommereau, J.-P., Redondas, A., Romahn, F., Valks, P., Van Roozendael, M., Xu, J., Zehner, C., Zerefos, C., and Zimmer, W.: TROPOMI/S5P total ozone column data: 
https://doi.org/10.5194/amt-2022-23

Preprint. Discussion started: 17 February 2022

(c) Author(s) 2022. CC BY 4.0 License.
Atmospheric

Measurement

Techniques

Discussions

global ground-based validation and consistency with other satellite missions, Atmos. Meas. Tech., 12, 5263-5287, doi: 10.5194/amt-125263-2019, 2019.

Gaudel, A., Cooper, O. R., Ancellet, G., Barret, B., Boynard, A., Burrows, J. P., Clerbaux, C., Coheur, P.-F., Cuesta, J., Cuevas, E., Doniki, S.,

Dufour, G., Ebojie, F., Foret, G., Garcia, O., Granados-Mu?oz, M. J., Hannigan, J., Hase, F., Hassler, B., Huang, G., Hurtmans, D., Jaffe, D., Jones, N., Kalabokas, P., Kerridge, B., Kulawik, S., Latter, B., Leblanc, T., Le Flochmo?n, E., Lin, W., Liu, J., Liu, X., Mahieu, E., McClure-Begley, A., Neu, J., Osman, M., Palm, M., Petetin, H., Petropavlovskikh, I., Querel, R., Rahpoe, N., Rozanov, A., Schultz, M. G., Schwab, J., Siddans, R., Smale, D., Steinbacher, M., Tanimoto, H., Tarasick, D., Thouret, V., Thompson, A. M., Trickl, T., Weatherhead, E., Wespes, C., Worden, H., Vigouroux, C., Xu, X., Zeng, G., and Ziemke, J.: Tropospheric Ozone Assessment Report: Present-day distribution and trends of tropospheric ozone relevant to climate and global atmospheric chemistry model evaluation. Elem Sci Anth, 6: 39. DOI: doi: 10.1525/elementa.291, 2018.

Gelaro, R., W. McCarty, M.J. Suárez, R. Todling, A. Molod, L. Takacs, C.A. Randles, A. Darmenov, M.G. Bosilovich, R. Reichle, K. Wargan, L. Coy, R. Cullather, C. Draper, S. Akella, V. Buchard, A. Conaty, A.M. da Silva, W. Gu, G. Kim, R. Koster, R. Lucchesi, D. Merkova, J.E. Nielsen, G. Partyka, S. Pawson, W. Putman, M. Rienecker, S.D. Schubert, M. Sienkiewicz, and B. Zhao, The Modern-Era Retrospective Analysis for Research and Applications, Version 2 (MERRA-2), J. Climate, 30, 5419-5454, https://doi.org/10.1175/JCLI-D-16-0758.1, 2017.

Hao, N., Koukouli, M. E., Inness, A., Valks, P., Loyola, D. G., Zimmer, W., Balis, D. S., Zyrichidou, I., Van Roozendael, M., Lerot, C., and Spurr, R. J. D.: GOME-2 total ozone columns from MetOp-A/MetOp-B and assimilation in the MACC system, Atmos. Meas. Tech., 7, 2937-2951, doi: 10.5194/amt-7-2937-2014, 2014.

410 Heue, K.-P., Coldewey-Egbers, M., Delcloo, A., Lerot, C., Loyola, D., Valks, P., and van Roozendael, M.: Trends of tropical tropospheric ozone from 20 years of European satellite measurements and perspectives for the Sentinel-5 Precursor, Atmos. Meas. Tech., 9, 5037-5051, doi: 10.5194/amt-9-5037-2016, 2016

Heue, K.-P., Spurr, R., Loyola, D., Van Roozendael, M., Lerot, C., and Xu, J.: ATBD for Total Ozone Column, S5P-L2-DLR-ATBD-400A, V2.1, issue 2.1, Feb. 2020a available at: http://www.tropomi.eu/documents/atbd last access Jan 2020.

Heue, K.-P., Eichmann, K.-U., Valks, P.: ATBD for Tropospheric Ozone Column, S5P-L2-DLR-ATBD-400C, V2.1, issue 2.1, Feb. 2020b available at: http://www.tropomi.eu/documents/atbd last access Jan 2020.

Huang, G., Liu, X., Chance, K., Yang, K., Bhartia, P. K., Cai, Z., Allaart, M., Ancellet, G., Calpini, B., Coetzee, G. J. R., Cuevas-Agull?, E., Cupeiro, M., De Backer, H., Dubey, M. K., Fuelberg, H. E., Fujiwara, M., Godin-Beekmann, S., Hall, T. J., Johnson, B., Joseph, E., Kivi, R., Kois, B., Komala, N., K?nig-Langlo, G., Laneve, G., Leblanc, T., Marchand, M., Minschwaner, K. R., Morris, G., Newchurch, M. J., Ogino, S.-Y., Ohkawara, N., Piters, A. J. M., Posny, F., Querel, R., Scheele, R., Schmidlin, F. J., Schnell, R. C., Schrems, O., Selkirk, H., Shiotani, M., Skriv?nkov?, P., St?bi, R., Taha, G., Tarasick, D. W., Thompson, A. M., Thouret, V., Tully, M. B., Van Malderen, R., V?mel, H., von der Gathen, P., Witte, J. C., and Yela, M.: Validation of 10-year SAO OMI Ozone Profile (PROFOZ) product using ozonesonde observations, Atmos. Meas. Tech., 10, 2455-2475, doi: 10.5194/amt-10-2455-2017, 2017.

Inness, A., Flemming, J., Heue, K.-P., Lerot, C., Loyola, D., Ribas, R., Valks, P., van Roozendael, M., Xu, J., and Zimmer, W.: Monitoring and assimilation tests with TROPOMI data in the CAMS system: near-real-time total column ozone, Atmos. Chem. Phys., 19, 3939-3962, doi: 10.5194/acp-19-3939-2019, 2019.

IPCC 2013. Climate Change 2013: The Physical Science Basis. In: Stocker, TF, Qin, D, Plattner, G-K, Tignor, M, Allen, SK, Boschung, J, Nauels, A, Xia, Y, Bex, V and Midgley, PM (eds.), Contribution of Working Group I to the Fifth Assessment Report of the Intergovernmental Panel on Climate Change, 1535. Cambridge University Press, Cambridge, United Kingdom and New York, NY, USA. 
Kleipool, Q. L., Dobber, M. R., de Haan, J. F., and Levelt, P. F.: Earth surface reflectance climatology from 3 years of OMI data, J. Geophys. Res., 113, D18308, doi:10.1029/2008JD010290, 2008.

Lefever, K., van der A, R., Baier, F., Christophe, Y., Errera, Q., Eskes, H., Flemming, J., Inness, A., Jones, L., Lambert, J.-C., Langerock, B., Schultz, M. G., Stein, O., Wagner, A., and Chabrillat, S.: Copernicus stratospheric ozone service, 2009-2012: validation, system intercomparison and roles of input data sets, Atmos. Chem. Phys., 15, 2269-2293, doi: 10.5194/acp-15-2269-2015, 2015.

Lerot, C. and Roozendael, M. Van and Lambert, J.-C. and Granville, J. and Gent, J. van and Loyola, D. and Spurr, R.: The GODFIT algorithm: a direct fitting approach to improve the accuracy of total ozone measurements from GOME. International Journal of Remote Sensing, 31 (2), 543-550. DOI: 10.1080/01431160902893576, 2010.

Loyola D., Koukouli M. E., Valks P., Balis D. S., Hao N., Van Roozendael M., Spurr R. J. D., Zimmer W., Kiemle S., Lerot C., Lambert J.-C., The GOME-2 total column ozone product: Retrieval algorithm and ground-based validation, Journal of Geophysical Research, vol. 116, D07302, 2011.

Loyola, D. G., Gimeno García, S., Lutz, R., Argyrouli, A., Romahn, F., Spurr, R. J. D., Pedergnana, M., Doicu, A., Molina Garc?a, V., and Sch?ssler, O.: The operational cloud retrieval algorithms from TROPOMI on board Sentinel-5 Precursor, Atmos. Meas. Tech., 11, 409-427, https://doi.org/10.5194/amt-11-409-2018, 2018

Loyola, D. G., Xu, J., Heue, K.-P., and Zimmer, W.: Applying FP_ILM to the retrieval of geometry-dependent effective Lambertian equivalent reflectivity (GE_LER) daily maps from UVN satellite measurements, Atmos. Meas. Tech., 13, 985-999, doi: 10.5194/amt-13-985-2020, 2020.

Miles, G. M., Siddans, R., Kerridge, B. J., Latter, B. G., and Richards, N. A. D.: Tropospheric ozone and ozone profiles retrieved from GOME-2 and their validation, Atmos. Meas. Tech., 8, 385?398, https://doi.org/10.5194/amt-8-385-2015, 2015.

McPeters, R. D., and Labow, G. J. (2012), Climatology 2011: An MLS and sonde derived ozone climatology for satellite retrieval algorithms, J. Geophys. Res., 117, D10303, doi:10.1029/2011JD017006.

McPeters, R. D., S. M. Frith, N. A. Kramarova, J. R. Ziemke, and G. L. Labow, OMI total column ozone: Extending the long-term data record (2018), Trend Quality Ozone from NPP OMPS: the Version 2 Processing, Atmos. Meas. Tech., doi:amt-2018-209, $2018,2017$.

Pan, X., Ichoku, C., Chin, M., Bian, H., Darmenov, A., Colarco, P., Ellison, L., Kucsera, T., da Silva, A., Wang, J., Oda, T., and Cui, G.: Six global biomass burning emission datasets: intercomparison and application in one global aerosol model, Atmos. Chem. Phys., 20, 969?994, https://doi.org/10.5194/acp-20-969-2020, 2020.

Ramonet, M., Wagner, A., Schulz, M., Christophe, Y., Eskes, H.J. , Basart, S., Benedictow, A., Bennouna, Y., Blechschmidt, A.-M., Chabrillat, S., Cuevas, E., El-Yazidi, A., Flentje, H., Hansen, K.M., Im, U., Kapsomenakis, J., Langerock, B., Richter, A., Sudarchikova, N., Thouret, V., Warneke, T. and Zerefos, C.: Validation report of the CAMS near-real-time global atmospheric composition service: Period June-August 2019, Copernicus Atmosphere Monitoring Service (CAMS) report, CAMS84_2018SC1_D1.1.1_JJA2019_v1.pdf, November 2019.

Rodgers C. Inverse methods for atmospheric sounding: theory and practice, series on atmospheric, oceanic and planetary physics, vol. 2.Singapore, New Jersey, London, Hong Kong: World Scientific; 2000.

Veefkind P., Keppens A., de Haan J.: ATBD for Ozone Profile, S5P-KNMI-L2-0004-RP,V1.0, Isuue 1.0, Oct. 2021.

Wu, S., L. J. Mickley, D. J. Jacob, J. A. Logan, R. M. Yantosca, and D. Rind: Why are there large differences between models in global budgets of tropospheric ozone? ,J. Geophys. Res.,112, D05302, doi:10.1029/2006JD007801, 2007. 
https://doi.org/10.5194/amt-2022-23

Preprint. Discussion started: 17 February 2022

(c) Author(s) 2022. CC BY 4.0 License.

(c) (1)

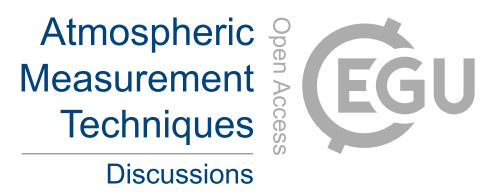

Ziemke, J. R., S. Chandra, and P. K. Bhartia, Two new methods for deriving tropospheric column ozone from TOMS measurements: The assimilated UARS MLS/HALOE and convective-cloud differential techniques, J. Geophys. Res., 103, 22,115-22,127, doi: 10.1029/98JD01567 1998

Ziemke, J. R., Chandra, S., Duncan, B. N., Froidevaux, L., Bhartia, P. K., Levelt, P. F., and Waters, J. W.: Tropospheric ozone determined from Aura OMI and MLS: Evaluation of measurements and comparison with the Global Modeling Initiative's Chemical Transport Model, J. Geophys. Res., 111, D19303, doi: 10.1029/2006JD007089, 2006.

Ziemke, J. R., Oman, L. D., Strode, S. A., Douglass, A. R., Olsen, M. A., McPeters, R. D., Bhartia, P. K., Froidevaux, L., Labow, G. J., Witte, J. C., Thompson, A. M., Haffner, D. P., Kramarova, N. A., Frith, S. M., Huang, L.-K., Jaross, G. R., Seftor, C. J., Deland, M. T., and Taylor, S. L.: Trends in global tropospheric ozone inferred from a composite record of TOMS/OMI/MLS/OMPS satellite measurements and the MERRA-2 GMI simulation, Atmos. Chem. Phys., 19, 3257-3269, doi: 10.5194/acp-19-3257-2019, 2019. 